\title{
Isolation of a multi-trait plant growth promoting Brevundimonas sp. and its effect on the growth of $B t$-cotton
}

\author{
Varun Kumar • Rajesh Gera
}

Received: 19 December 2012/ Accepted: 21 February 2013/Published online: 13 March 2013

(C) The Author(s) 2013. This article is published with open access at Springerlink.com

\begin{abstract}
Arid regions pose a serious problem for crop production by suppressing plant growth. The use of plant growth promoting rhizobacteria (PGPR) as bioinoculant may be promising to enhance the crop yield in arid conditions. In the present investigation, four strains of cultivable bacteria associated with the rhizosphere of Saccharum L. grown in arid region were isolated using $\mathrm{N}$-free media. Assessment of their nitrogen-fixing ability through amplification of nif $\mathrm{H}$ gene showed the presence of nifH gene (390 bp) in only one (MDB4) of the four isolates. The nitrogen-fixing potential of this isolate was confirmed by the presence of nitrogenase activity determined using acetylene reduction assay. The diazotrophic MDB4 isolate also exhibited other PGPR traits, such as the production of indole-3-acetic acid (IAA) and ammonia. In pot experiments, inoculation of Bt-cotton seeds with MDB4 enhanced the growth of plants as shown by significant increase in plant height $(68.41 \%)$, shoot dry weight $(58.44 \%)$ and root dry weight $(64.81 \%)$ over untreated control. The MDB4 strain was Gram negative and identified as Brevundimonas sp. on the basis of phenotypic, biochemical, phylogenetic and 16S rRNA gene sequencing data. It is concluded that the MDB4 bacterial strain having different plant growth promoting activities can be considered as a beneficial microbe for sustainable agriculture in arid regions.
\end{abstract}

R. Gera $(\square)$

Department of Microbiology, CCS Haryana Agricultural

University, Hisar 125004, India

e-mail: rajeshgera1967@gmail.com

\section{Kumar}

Department of Biotechnology and Bioinformatics, Jaypee University of Information Technology, Waknaghat 173234, HP, India
Keywords Plant growth promoting rhizobacteria - nif $\mathrm{H}$. Indole-3-acetic acid $\cdot$ Bt-cotton $\cdot$ Brevundimonas sp.

\section{Introduction}

The arid zone of India covers an area of 38.7 million hectare ( $\mathrm{m} \mathrm{ha}$ ), out of which $31.7 \mathrm{~m}$ ha comes under hot arid zone (Gothwal et al. 2008). In the arid zone, temperature raises up to $50{ }^{\circ} \mathrm{C}$ with average rainfall $<200 \mathrm{~mm}$ causing severe conditions for most of the life forms besides poor nutritional status of such soils (Bhatnagar and Bhatnagar 2005). The soil fertility in these areas can be enhanced using bioinoculants. The use of plant growthpromoting rhizobacteria (PGPR) is also known to improve plant growth and yield (Vessey 2003; Abbasi et al. 2011).

PGPR are native soil bacteria that colonize the rhizosphere or plant roots resulting in stimulation of plant growth either directly and/or indirectly. In the recent years, PGPR have received worldwide importance for agricultural benefits, as a diverse array of bacteria, including species of Rhizobium, Agrobacterium, Pseudomonas, Azospirillum, Azotobacter, Bacillus, Klebsiella and many others that have been shown to facilitate plant growth both under greenhouse and field conditions (Farina et al. 2012). The use of PGPR is steadily increasing in agriculture and offers an attractive way to replace chemical fertilizers, pesticides and supplements (Rani and Arundhati 2012). The mechanisms through which PGPR stimulate plant growth and development are not fully understood, but are believed to include (a) production of phytohormones; (b) nitrogen fixation; (c) solubilization of inorganic phosphate and mineralization of organic phosphate; (d) production of siderophores that chelate iron and make it available to plant root; and (e) antagonism against phytopathogenic 
microorganisms by the synthesis of antibiotics, enzymes or fungicidal compounds, as well as competition with harmful microorganisms (Glick 1995; Weyens et al. 2009; Abbasi et al. 2011).

Biological nitrogen fixation by bacteria present in the rhizosphere is an important property contributing to plant growth (Gothwal et al. 2008). Nitrogenase complex, the enzyme that catalyzes biological dinitrogen reduction to ammonium, is composed of two highly conserved proteins: the iron protein, also known as nitrogenise reductase (encoded by the nifH gene) and the molybdenum iron protein, also known as dinitrogenase (encoded by the nif$D K$ genes). The nifH genes encoding the iron-protein component of nitrogenase enzyme are evolutionarily conserved and highly valuable for phylogenetic analysis and detection and identification of diazotrophs by cultivationindependent methods (Ueda et al. 1995).

Although Brevundimonas sp. has been used as PGPR in enhancing growth of wheat plants (Rana et al. 2011), its effect on the growth of $B t$-cotton has not yet been investigated. Cotton is an important commercial crop which meets nearly $75 \%$ of total raw material needs of the textile industry in India. Research on cotton under various soil and climatic conditions has revealed the beneficial effect of nitrogen application on growth, yield and quality of cotton (Narayanan et al. 1974). Thus, it was envisaged that inoculation of cotton with diazotrophic PGPR would enhance the plant growth by supplying nitrogen. The present study reports the isolation and identification of multi-trait Brevundimonas sp. having nitrogen fixing ability as well as other plant growth promoting activities and evaluation of its effect on the growth of Bt-cotton. This is the first report on Brevundimonas sp. from arid region that elicits plant growth promotion on $B t$-cotton plant.

\section{Materials and methods}

A rhizospheric soil sample of sugarcane (Saccharum L.) collected from Bhoria khera, district Sirsa (latitude: $29^{\circ} 30^{\prime} \mathrm{N}$, longitude: $75^{\circ} 18^{\prime} \mathrm{E}$ ), an arid region of Haryana (India), was used for isolation of PGPR. Bacteria from the soil sample were isolated by serial dilution method on DB agar plates which contained (in g/L); malic acid (5.0), dipotassium hydrogen phosphate $(0.6)$, potassium dihydrogen orthophosphate $(0.4)$, manganese sulphate $(0.01)$, magnesium sulphate (0.05), sodium chloride (0.02), sodium molybdate (0.002), potassium hydroxide (4.0) and bromothymol blue ( $2 \mathrm{~mL}$ of $0.5 \%$ alcoholic solution), $\mathrm{pH}$ 6.8. The plates were incubated at $37{ }^{\circ} \mathrm{C}$ in a bacteriological incubator. After 4-5 days of incubation, distinct morphotypes of bacteria were screened on the basis of colony color, shape and size. Each morphotype was purified by re- streaking on fresh DB agar plate and the purified isolates were maintained on DB slants at $4{ }^{\circ} \mathrm{C}$.

Genomic DNA of each morphotype was isolated using CTAB method (Ausubel et al. 1987) and subjected to the amplification of nifH gene using nifH primers; 19F (5'-GCIWTYTAYGGIAARGGIGG-3') and 407R (5'-AAI CCRCCRCAIACIACRTC-3') (Ueda et al. 1995). The PCR reaction mixture $(25 \mu \mathrm{l})$ contained $2 \mu \mathrm{l}$ template DNA (0.1-0.14 $\mu \mathrm{g}^{-1}$ ), $2 \mu \mathrm{l}$ of each primer (10 pmol each), $12.5 \mu \mathrm{l}$ of Red Taq Ready Mix (Bangalore Genei, India) and $6.5 \mu \mathrm{l}$ sterile water. The conditions for PCR were: initial denaturation at $95{ }^{\circ} \mathrm{C}$ for $4 \mathrm{~min}, 35$ cycles of denaturation at $94{ }^{\circ} \mathrm{C}$ for $30 \mathrm{~s}$ each, annealing at $54{ }^{\circ} \mathrm{C}$ for $1 \mathrm{~min}$ and extension at $72{ }^{\circ} \mathrm{C}$ for $1 \mathrm{~min}$ followed by a final extension at $72{ }^{\circ} \mathrm{C}$ for $5 \mathrm{~min}$. The PCR was then set on hold at $4{ }^{\circ} \mathrm{C}$. The amplified nifH gene was checked by $2 \%$ agarose gel electrophoresis and visualized by observing UV fluorescence using gel documentation system (MiniBis Pro, DNR Bio Imaging Systems, US).

The nitrogen-fixing potential of the bacterial isolates was evaluated by measuring their nitrogenase activity using acetylene reduction assay (Boddey 1987). Plant growth promoting abilities were determined as per the standard methods: IAA (Gordon and Weber 1951), phosphate solubilization (Pikovskaya 1948), ammonia production (Cappuccino and Sherman 1992) and siderophore production (Schwyn and Neilands 1987).

The effect of the PGPR isolate on the growth of $B t$ cotton plants was determined through a pot culture experiment. The experiment was conducted in a completely randomized design, with three replicates. The Bt-cotton crop was raised in earthen pots $\left(8^{\prime \prime}\right.$ size) filled with $5-\mathrm{kg}$ non-sterile soil taken from CCS HAU fields (latitude: $29^{\circ} 10^{\prime} \mathrm{N}$ and longitude: $75^{\circ} 46^{\prime} \mathrm{E}$ ) and irrigated regularly to maintain $60 \%$ water holding capacity of the soil. The recommended doses of fertilizers NPK (urea, single super phosphate and Muriate of potash in the ratio $70: 27: 10 \mathrm{~kg}^{-1}$ $\mathrm{ha}^{-1}$ ) were applied before sowing. Seeds of $B t$-cotton (var. $\mathrm{RCH}$ 134) were surface sterilized by exposing these to $95 \%$ ethanol followed by immersing in $0.2 \%$ mercuric chloride solution for $3 \mathrm{~min}$ and rinsing ten times with sterile distilled water. The bacterial culture was grown in $\mathrm{LB}$ medium at $28{ }^{\circ} \mathrm{C}$ to attain 0.6 O.D. at $540 \mathrm{~nm}\left(10^{8}-10^{9}\right.$ cells $\mathrm{mL}^{-1}$ ). $1 \mathrm{~mL}$ of this overnight grown bacterial suspension was applied on each $B t$-cotton seed for $10 \mathrm{~min}$ followed by sowing of the seeds ( 5 in each pot) to a depth of $5 \mathrm{~mm}$. In control, seeds were treated with sterile LB medium instead of the bacterial suspension. The seeds of Bt-cotton (var. RCH 134) were also inoculated with the reference bacterial strain (HT-54) in a manner similar to MDB4 for comparison. The pots were kept in sunlight. After emergence, seedlings were thinned to three per pot. Plants were irrigated with only distilled water (without 
micro and macro nutrients). Plants were harvested after 90 days of sowing and dried to a constant weight at $65^{\circ} \mathrm{C}$. Plant height and dry weight of the plants were determined. Statistical analysis was performed by subjecting the triplicate sets of data to ANOVA (Analysis of Variance) using MINITAB version 15.0 and Tukey's tests $(P=0.05)$.

Biochemical characteristics of the MDB strain were determined using HiCarbohydrate ${ }^{\mathrm{TM}}$ Kit (HiMedia, India). Oxidase test was performed by dispensing a bacterial colony on the filter paper soaked in $N, N, N^{\prime}, N^{\prime}$-tetramethyl- $p$ phenylenediamine dihydrochloride and examining it for the appearance of blue color which indicates a positive test. Catalase activity was estimated by monitoring the production of bubbles from $3 \%$ hydrogen peroxide solution. Gram staining of the bacterial isolate was performed as per the method of Beveridge (2001). PCR amplification of 16S rRNA gene was carried out using primers fD1 ( $5^{\prime}$-AGA GTT TGA TCC TGG CTC AG- $3^{\prime}$ ) and rP2 (5'-ACG GCT ACC TTG TTA CGA CTT-3') (Weisburg et al. 1991). PCR reaction mixture $(50 \mu \mathrm{l})$ contained $2 \mu \mathrm{l}$ template DNA (50-70 ng $\left.\mu \mathrm{l}^{-1}\right), 2 \mu \mathrm{l}$ of each primer $(10 \mu \mathrm{M}), 1 \mu \mathrm{l}$ of $10 \mathrm{mM}$ dNTPs, $5 \mu \mathrm{l}$ of Taq buffer (10X), $1 \mu \mathrm{l}$ of Taq DNA polymerase $\left(3 \mathrm{U}^{-1} \mathrm{l}^{-1}\right.$ ) (Fermentas, US) and $12.0 \mu \mathrm{l}$ of Millipore water. The conditions used for PCR were: initial denaturation at $94{ }^{\circ} \mathrm{C}$ for $3 \mathrm{~min}, 40$ cycles of denaturation at $94{ }^{\circ} \mathrm{C}$ for $30 \mathrm{~s}$ each, annealing at $50{ }^{\circ} \mathrm{C}$ for $30 \mathrm{~s}$ and extension at $72{ }^{\circ} \mathrm{C}$ for $1 \mathrm{~min}$ followed by a final extension at $72{ }^{\circ} \mathrm{C}$ for $10 \mathrm{~min}$. The PCR was then set on hold at $4{ }^{\circ} \mathrm{C}$. PCR products were analysed by $1.5 \%$ agarose gel electrophoresis and visualized by observing UV fluorescence using gel documentation system. The purified 16S rRNA gene was sequenced (Bioserve, Hyderabad, India) by primer walking using five different internal primers (16SEQ2R, 16SEQ3F, INS16SREV, 16SEQ4R and 16SEQ4F) and the sequence obtained in FASTA format was compared to the GenBank database using the algorithm BLASTN program to identify the most similar $16 \mathrm{~S}$ rRNA gene sequences. The reference sequences were downloaded in FASTA format from NCBI database (http://www.ncbi.nlm.nih.gov) and the phylogenetic tree was constructed by the neighbour-joining method (Saitou and Nei 1987) using MEGA4 software (Tamura et al. 2007). Tree topologies were evaluated by performing bootstrap analyses using 1,000 re-samplings.

\section{Results and discussion}

Plant growth promoting rhizobacteria enhance growth and development of plants by exploiting different mechanisms. In this study, we have isolated a multi-trait PGPR in nitrogen-free media from the rhizosphere of Saccharum L. grown in the arid region and used it as bioinoculant for Bt-cotton.
On pouring the serially diluted soil sample on $\mathrm{DB}$ agar plates, four distinct bacterial morphotypes (MDB1, MDB2, MDB3 and MDB4) were obtained on the basis of their colony color, shape and size. To test the nitrogen fixing ability of the isolates, genomic DNA from all the four strains was isolated and subjected to amplification of the nif $\mathrm{H}$ gene. The results revealed that only one (MDB4) of the four strains showed nif $\mathrm{H}$ gene amplification with size of the amplified product as $390 \mathrm{bp}$. Attempts to amplify nif $\mathrm{H}$ from genomic DNA of the remaining three isolates using different sets of primers (Sarita et al. 2008) also failed indicating the absence of nitrogen fixing genes in these strains. Since the nifH gene is evolutionarily conserved among diazotrophs and could be used for their identification (Ueda et al. 1995), the presence of the nif $\mathrm{H}$ gene indicated that the MDB4 isolate was capable of nitrogen fixation. The MDB4 strain exhibited nitrogenase activity (47.90 nmol ethylene $\mathrm{mg}^{-1}$ protein $\mathrm{h}^{-1}$ ) which confirmed its nitrogen-fixing ability.

The evaluation of other plant growth promoting activities of the strain MDB4 revealed that it produced indole-3acetic acid $\left(364.1 \pm 0.750 \mu \mathrm{gmL}^{-1}\right)$ and ammonia $\left(0.954 \pm 0.006 \mu \mathrm{gmL}^{-1}\right)$; however, it neither solubilized phosphorus in Pikovskaya medium containing tricalcium phosphate nor produced siderophores. Thus, the bacterial strain isolated from the sugarcane rhizoshere was a multitrait PGPR which exhibited nitrogen-fixing ability and production of indole-3-acetic acid as well as ammonia. These plant growth promoting characteristics of the isolated strain would enhance the growth and yield of plants as suggested by several researchers (Farina et al. 2012; Glick 1995). The production of phytohormones is usually used to explain the various direct effects of PGPR on plants (Patten and Glick 1996). PGPR with the ability to fix biological nitrogen would have an advantage in counterbalancing the loss of nitrogen from soils.

The potential of the multi-trait MDB4 isolate on plant growth promotion was evaluated by using it as bioinoculant for Bt-cotton in pot experiments. A reference strain (HT-54) was also used as inoculant for comparison. Data obtained from this experiment showed stimulatory effects on plant height and dry weights of root and shoot after inoculation with MDB4 isolate and HT-54. The increase in plant height, shoot dry weight and root dry weight on inoculation with MDB4 strain was 68.41, 58.44 and $64.81 \%$, respectively, whereas the corresponding increase on inoculation with HT-54 strain was 48.96, 10.23 and $5.55 \%$ (Table 1). So, the MDB4 strain was found to be more effective as compared to HT-54 in promoting plant growth which could be attributed to its nitrogen-fixing ability. A similar increase in biomass of canola plants following inoculation with bacterial strains Achromobacter, Klebsiella, Pseudomonas, Pantoea and Chryseobacterium has been reported (Farina et al. 2012). Nitrogen is one 
of the factors that directly influence vegetative growth and dry matter production. Decreased dry matter production associated with boll shedding process in cotton was due to nitrogen deficiency (Jackson and Gerik 1990). Ian (2006) indicated that nitrogen enhanced the cry protein concentration in the cotton plant which gave more protection to the crop from pest incidence. These reports might imply that diazotrophic nature of MDB4 was one of the factors responsible for enhanced plant height and dry weight. These findings implied that the isolated PGPR strain could be considered as plant growth promoter.
The evaluation of biochemical characteristics of the strain MDB4 showed it positive for catalase and oxidase, but negative for urease production, starch hydrolysis and nitrate reduction. The strain was also able to utilize carbohydrates viz. D-glucose, galactose, maltose and cellobiose as energy sources. Mannose, trehalose, sucrose, mannitol, fructose, ribose, xylose and raffinose were not utilized as energy sources. These tests helped in identification of its genera as Brevundimonas (Holt et al. 1994). The partial 16S rRNA gene sequence of multi-trait PGPR strain obtained in this study was submitted in GenBank

Table 1 Plant height (H), Shoot dry weight (S) and Root dry weight (R) of Bt cotton plant inoculated with HT-54 (reference strain) and MDB4 isolate

\begin{tabular}{|c|c|c|c|c|c|c|}
\hline \multirow[t]{2}{*}{ Treatment } & \multirow[t]{2}{*}{ Plant height $(\mathrm{cm})$} & \multirow[t]{2}{*}{ Shoot dry weight (g/plant) } & \multirow[t]{2}{*}{ Root dry weight (g/plant) } & \multicolumn{3}{|c|}{ Difference from control } \\
\hline & & & & $\mathrm{H}$ & $S$ & $\mathrm{R}$ \\
\hline Control & $29.98 \pm 0.60$ & $6.45 \pm 0.38$ & $0.91 \pm 0.08$ & - & - & - \\
\hline HT-54 & $44.66 \pm 1.88$ & $7.11 \pm 0.39$ & $1.14 \pm 0.07$ & $14.68 * * *$ & $0.66^{\#}$ & $0.23^{\#}$ \\
\hline MDB4 & $50.49 \pm 1.81$ & $10.22 \pm 0.69$ & $1.89 \pm 0.24$ & $20.51 * * *$ & $3.77 * *$ & $0.98 *$ \\
\hline
\end{tabular}

Group 1: Plant height; Group 2: Shoot dry weight; Group 3: Root dry weight. Data represent the mean \pm SEM in each group. Comparisons were also made between group 1 and group $2(P<0.001)$; group 1 and group $3(P<0.001)$; group 2 and $3(P<0.05)$

*** $P<0.001$; ** $P<0.01 ; * P<0.05$ and ${ }^{\#}$ non-significant

Fig. 1 Phylogenetic tree showing the position of strain MDB4, Brevundimonas species and some other related taxa (Genbank accession numbers are given in parentheses) based on $16 \mathrm{~S}$ rDNA gene sequences. Distances were calculated by neighbour-joining method. Numbers at branch points are bootstrap values (expressed as percentages of 1,000 replications). Rhodospirillum rubrum D30778 was used as an outgroup. Bar 0.02 substitutions per nucleotide position

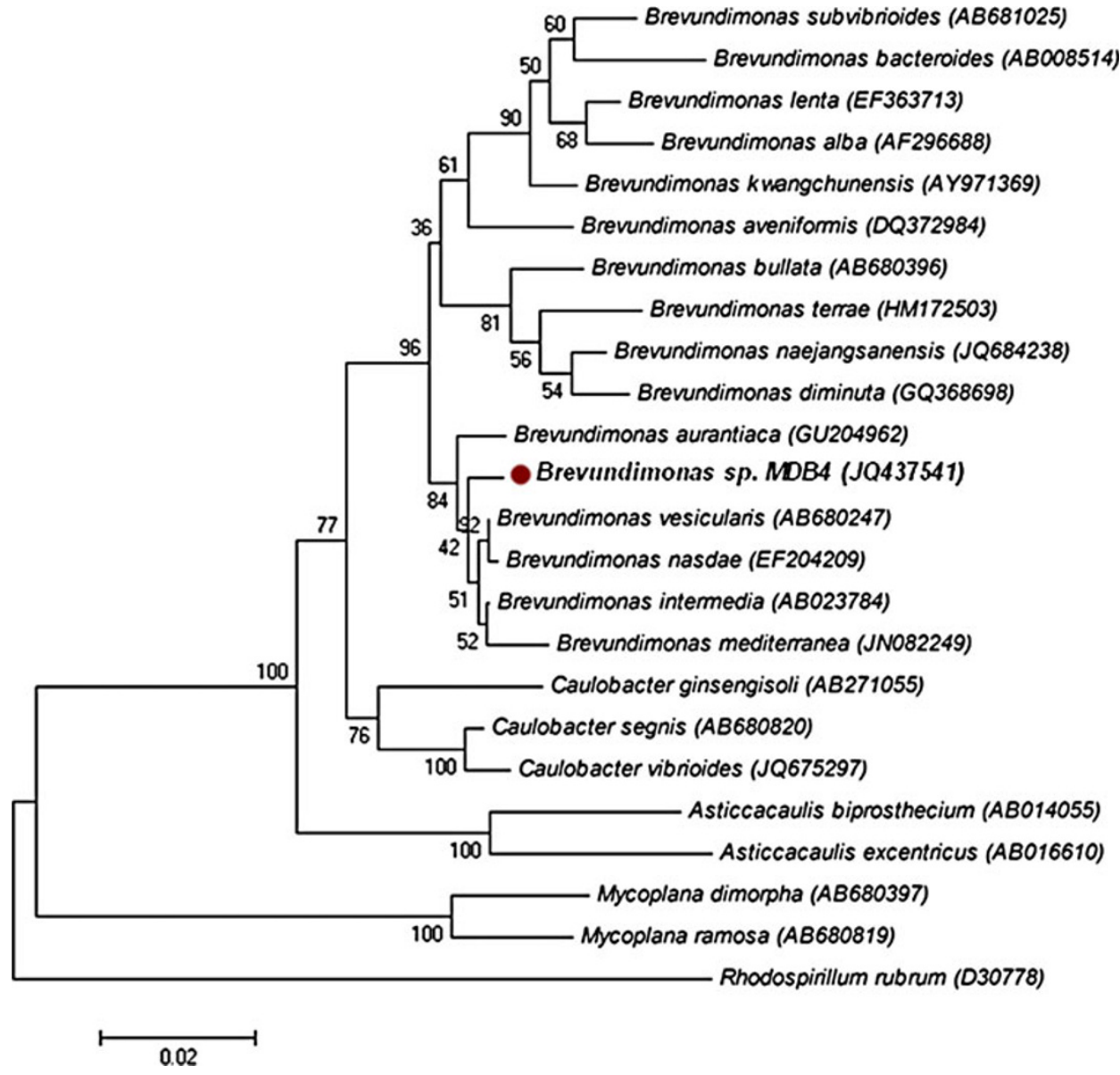


database (http://www.ncbi.nlm.nih.gov) under the accession number JQ437541 (Brevundimonas sp. MDB4). The 16S rRNA gene sequencing data of the bacterial isolate MDB4 showed $99 \%$ similarity with the Brevundimonas sp. In the phylogenetic tree based on the neighbour joining method, the strain MDB4 fell within the cluster comprising Brevundimonas species (Fig. 1). Brevundimonas sp. MDB4 exhibited 16S rRNA gene sequence similarity values of 88.7-99.5\% to the type strains of Brevundimonas species and 82.2-99.2\% to other species included in the phylogenetic analysis. Identification of Brevundimonas sp. using 16S rRNA gene sequencing was supported by many researchers (Yoon et al. 2007). On the basis of phenotypic, phylogenetic and 16S rRNA gene sequencing data, the MDB4 isolate was identified as Brevundimonas sp.

Overall, the plant growth promoting properties of the Brevundimonas sp. MDB4 and its effect on Bt-cotton plant growth under control conditions suggest that this strain has a potential of being developed as bio-inoculant and is likely to be a promising strain for application in agriculture under Arid regions.

Acknowledgments This research work is a part of the AMAAS project funded by National Bureau of Agriculturally Important Microorganisms (NBAIM) and Mau Nath Bhanjan. The authors are grateful to these funding agencies.

Conflict of interest The authors declare that they have no conflict of interest.

Open Access This article is distributed under the terms of the Creative Commons Attribution License which permits any use, distribution, and reproduction in any medium, provided the original author(s) and the source are credited.

\section{References}

Abbasi MK, Sharif S, Kazmi M, Sultan T, Aslam M (2011) Isolation of plant growth promoting rhizobacteria from wheat rhizosphere and their effect on improving growth, yield and nutrient uptake of plants. Plant Biosyst 145:159-168

Ausubel FM, Brent R, Kingston R (1987) Current Protocols in Molecular Biology. Wiley, New York

Beveridge TJ (2001) Use of Gram stain in microbiology. Biotech Histochem 76:111-118

Bhatnagar A, Bhatnagar M (2005) Microbial diversity in desert ecosystems. Curr Sci 89:91-100

Boddey RM (1987) Methods for quantification of nitrogen fixation associated with gramineae. Crit Rev Plant Sci 6:209-266

Cappuccino JG, Sherman N (1992) Microbiology: a laboratory manual. Addison-Wesley, New York

Farina R, Beneduzi A, Ambrosini A, de Campos SB, lisboa BB, Wendisch V, Vargas LK, Passaglia LMP (2012) Diversity of plant growth-promoting rhizobacteria communities associated with the stages of canola growth. Appl Soil Ecol 55:44-52

Glick BR (1995) The enhancement of plant growth by free-living bacteria. Can J Microbiol 41:109-117

Gordon AS, Weber RP (1951) Colorimetric estimation of indole acetic acid. Plant Physiol 26:192-195

Gothwal RK, Nigam VK, Mohan MK, Sasmal D, Ghosh P (2008) Screening of nitrogen fixers from rhizospheric bacterial isolates associated with important desert plants. Appl Ecol Eviron Res 6(2):101-109

Holt JG, Krieg NR, Sneath PHA, Staley JT, Williams ST (1994) Bergey's manual of determinative bacteriology, 9th edn. Williams and Wilkins, Baltimore

Ian RJ (2006) Effect of genotype, edaphic, environmental conditions and agronomic practices on Cry $1 \mathrm{AC}$ protein expression in transgenic cotton. J Cotton Sci 10:252-262

Jackson BS, Gerik TJ (1990) Boll shedding and boll load in nitrogen stressed cotton. Agron J 82:483-488

Narayanan SS, Balasubramaniam N, Subbaiah S, Chinna Durai K (1974) Influence of plant density and nitrogen levels on the yield of irrigated American cotton. Madras Agr J 61:865-866

Patten C, Glick B (1996) Bacterial biosynthesis of indole-3-acetic acid. Can J Microbiol 42:207-220

Pikovskaya RI (1948) Mobilization of phosphorus in soil in connection with vital activity of some microbial species. Microbiologia 17:362-370

Rana A, Saharan B, Joshi M, Prasanna R, Kumar K, Nain L (2011) Identification of multi- trait PGPR isolates and evaluating their potential as inoculants for wheat. Ann Microbiol 61:893-900

Rani MU, Arundhati Reddy G (2012) Screening of rhizobacteria containing plant growth promoting (PGPR) traits in rhizosphere soils and their role in enhancing growth of pigeon pea. Afr J Biotechnol 11(32):8085-8091

Saitou N, Nei M (1987) The neighbour-joining method: a new method for reconstructing phylogenetic trees. Mol Biol Evol 4(4): 406-425

Sarita S, Priefer UB, Prell J, Sharma PK (2008) Diversity of nifH gene amplified from rhizosphere soil DNA. Curr Sci 94:109-115

Schwyn B, Neilands JB (1987) Universal chemical assay for the detection and determination of siderophores. Anal Biochem 160: $47-56$

Tamura K, Dudley J, Nei M, Kumar S (2007) MEGA4: molecular evolutionary genetics analysis (MEGA) software version 4.0. Mol Biol Evol 24:1596-1599

Ueda T, Suga Y, Yahiro N, Matsuguchi T (1995) Remarkable $\mathrm{N}_{2^{-}}$ fixing bacterial diversity detected in rice roots by molecular evolutionary analysis of nif $\mathrm{H}$ gene sequences. J Bacteriol 177:1414-1417

Vessey JK (2003) Plant growth promoting rhizobacteria as biofertilizers. Plant Soil 255:571-586

Weisburg WG, Barns SM, Pelletier DA, Lane DJ (1991) 16S ribosomal DNA amplification for phylogenetic study. J Bacteriol 173:697-703

Weyens N, Lelie DVD, Taghavi S, Newman L, Vangronsveld J (2009) Exploiting plant-microbe partnerships to improve biomass production and remediation. Trends Biotechnol 27: 591-598

Yoon JH, Kang SJ, Lee JS, Oh HW, Oh TK (2007) Brevundimonas lenta sp. nov., isolated from soil. Int J Sys Evol Microbiol 57:2236-2240 